
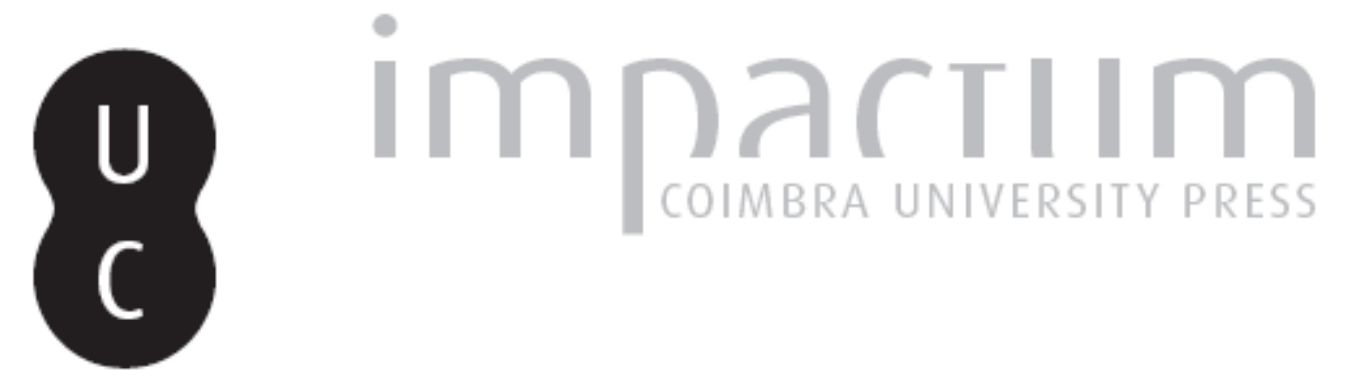

Tafuri on hous-'ing': housing history as city-making praxis

Autor(es): Davidovici, Irina

Publicado por: Editorial do Departamento de Arquitetura

URL persistente:

URI:http://hdl.handle.net/10316.2/43459

DOI:

DOl:https://doi.org/10.14195/1647-8681_8_2

Accessed : $\quad$ 26-Apr-2023 11:24:14

A navegação consulta e descarregamento dos títulos inseridos nas Bibliotecas Digitais UC Digitalis, UC Pombalina e UC Impactum, pressupõem a aceitação plena e sem reservas dos Termos e Condições de Uso destas Bibliotecas Digitais, disponíveis em https://digitalis.uc.pt/pt-pt/termos.

Conforme exposto nos referidos Termos e Condições de Uso, o descarregamento de títulos de acesso restrito requer uma licença válida de autorização devendo o utilizador aceder ao(s) documento(s) a partir de um endereço de IP da instituição detentora da supramencionada licença.

Ao utilizador é apenas permitido o descarregamento para uso pessoal, pelo que o emprego do(s) título(s) descarregado(s) para outro fim, designadamente comercial, carece de autorização do respetivo autor ou editor da obra.

Na medida em que todas as obras da UC Digitalis se encontram protegidas pelo Código do Direito de Autor e Direitos Conexos e demais legislação aplicável, toda a cópia, parcial ou total, deste documento, nos casos em que é legalmente admitida, deverá conter ou fazer-se acompanhar por este aviso. 


\section{Irina Davidovici}

ETH Zürich

\section{'T' afuri on I-Ious-'ing': I-Iousing \\ I-Iistory as $\mathrm{C}_{\mathrm{it}}$-y-malaing Praxis}

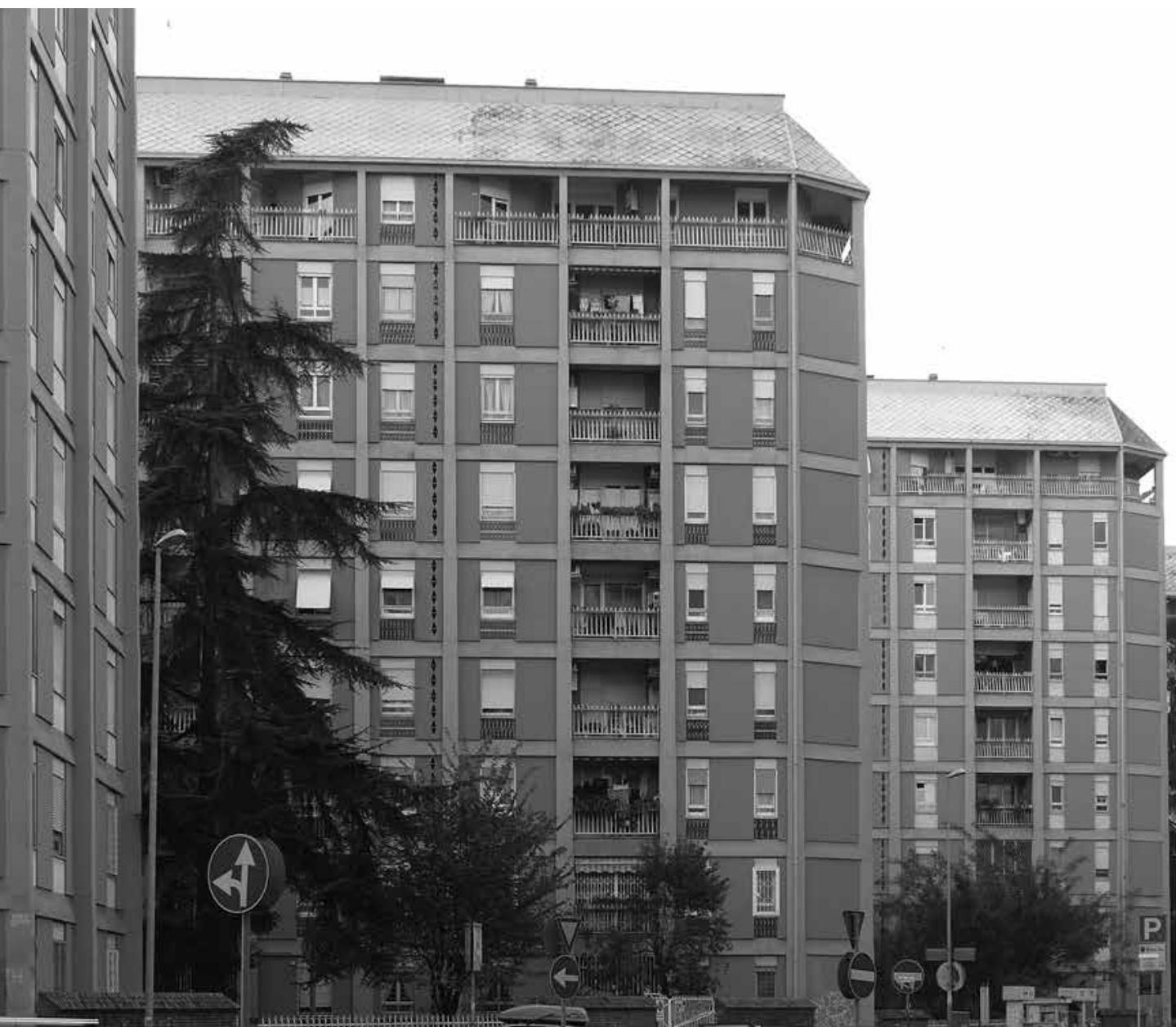


One of the most powerful agents of urban transformation in the twentieth century has been the mass production of housing, both in the inner densification and outward expansion of European cities. For this reason, historical accounts of urban housing programmes of any significant scale cannot be innocent: they trace the transformation of theoretical discourses into practices of city-making. The ideas for residential districts described in the experimental interwar urbanism of Le Corbusier and Ludwig Hilberseimer transitioned, under the pressures of post-war reconstruction, into actual, vast quartiers of prefabricated towers and slabs. This centrifugal growth was achieved with wildly varying degrees of success, depending not so much on architectural quality as on issues of social mix, soundness of supporting infrastructure and efficiency of administrative networks. More recently, in reaction to the scale and ubiquity of urban decentralisation, earlier and quantitatively lesser efforts towards densification have come under renewed scrutiny. Previously ignored on account of their anonymity and pragmatism, they have attracted attention for their consolidating effect on the urban as well as social fabric. The compact, fortress-like reform estates built during the late $19^{\text {th }}$ century on slum clearance sites in London, the idealist yet compromised ceinture rouge blocks that rose in place of the demolished Parisian fortifications between the wars, the speculative and typologically diverse developments on the outskirts of Rome, or the peculiar episode of Red Vienna's networked Gemeindebauten evoke more nuanced relations between housing and cities, individuals and communities ${ }^{1}$. While proportionately few in comparison with suburban housing, those ensembles that retained by various means their continuity with the adjacent urban fabric are qualitatively, historically and ideologically significant. The appeal of such projects resides in the tension between their desire for internal coherence and the various ways - spatial, morphological, typological in which they are anchored in a larger urban and cultural continuum.

Unlike the history of houses, that of hous-ing is inescapably political, which means that its correct understanding and interpretation poses specific challenges to the historian. Due to its subject's reliance on policy, housing historiography performs an endless balancing act between the resolution of forms and the immaterial determining factors, political, ideological and administrative. Manfredo Tafuri was the first to formalise this movement in his research at the Institute of Architectural History in Venice, part of the Istituto Universitario di Architettura IUAV ${ }^{2}$.

Tafuri argued that a general "crisis of the object" was reflected by a methodological crisis in the history of architecture, in which the formal qualities of projects remained at odds with their involvement in a political, social and historical context (Tafuri, 1980, p. 85). This applied most clearly to the study of housing, that architectural embodiment of the industrial urban masses to which the Marxist critic dedicated some of his most convincing historical tracts. Tafuri's assessment of the German modernist Siedlungen as "oases of order... built utopias
Frontispiece Mario Ridolfi and Wolfgang Frankl. INA-Assicurazioni residential towers in Viale Etiopia, Rome, 1950-54.

Photo: Irina Davidovici 
at the edge of an urban reality little conditioned by them" laid bare the tension between the rational order of architectural visions and the potent disorder of their actual settings (Tafuri, 1976, p. 109).

His commentaries on post-war Italian housing exposed a parallel predicament, as the "islands of realised utopia" intended by architects were eventually caught up, and ultimately compromised, by ubiquitous processes of speculative urban growth around them (Tafuri, 1989, p. 33). Tafuri's pronouncements on German pre-war and Italian post-war models starkly summarised the dilemma of autonomy and integration still faced by urban housing production throughout Europe. From the various pronouncements that Tafuri made on the history of housing, one might be able to reconstitute a trajectory of ideas regarding citymaking throughout the twentieth century.

This paper attempts to sketch out this history of housing as urban practice. At the same time, it re-evaluates the critical instruments at the disposal of the housing historian, distilling from Tafuri's analyses of twentieth-century housing a research methodology that can be reproduced. Concentrating on the modernist failure to gain control over urban contradictions, Tafuri's housing histories submitted projects to structuralist readings with Marxist and Freudian overtones, oscillating between form-oriented and process-oriented methods of analysis. How did this pendulum between the object and its framework affect the understanding of housing production? How can his concept of historical analysis as a contradictory, complex and constantly renewable operation form the basis of a more general methodology? How can static morphological and typological classifications be placed alongside the more dynamic constituents of social and political reality?

Tafuri's and his collaborators' studies on European housing combined object critique with ideological analysis to illustrate the confrontation between mass housing, urban strategy and the allconditioning capitalist apparatus. Instead of advancing a generalised understanding of the avant-garde as a modernist phenomenon gliding across national and political boundaries, the historical writings addressed the local specificity of parallel developments, such as those of interwar German, Austrian or Dutch housing policies (Tafuri and Dal Co, 1980). Distinctions were drawn on the basis of specific political and administrative conditions, rather than chronological or geographical contexts. The individual architectural approaches identified within each of these separate cultural and political tracts opened a discursive range, rather than illustrating one defining attitude. All such distinctions were subsumed under a greater phenomenon, which Tafuri repeatedly described as a series of successive, and ultimately failing, ideologies. Beneath the various scenarios offered by European and US housing histories, he thus articulated the common, recurring drama of a misalignment between architectural means and political ends.

Housing received special attention in Tafuri's 1969 Contropiano article "The Critique of Architectural Ideology", later expanded as 
Architecture and Utopia (Tafuri, 1969, 1976). In these pieces, Tafuri used big strokes to articulate, in K. Michael Hays' words, "the entire cycle of modernism as a unitary development in which the avantgardes' visions of utopia come to be recognized as an idealization of capitalism, a transfiguration of the latter's rationality into the rationality of the autonomous form" (Hays, 1998, p. 2). In contrast, the more detailed historical tracts of the Vienna Rossa anthology (Tafuri, 1980), Architettura Contemporanea, co-authored with Francesco Dal Co (Tafuri and Dal Co, 1980), and the History of Italian Architecture (Tafuri, 1989) articulated a more nuanced commentary, oscillating between the analysis of housing projects as built artefacts and as visible manifestations of particular ideologies. In order to extract a common method, we should begin by reviewing some of these commentaries on social housing experiments: in the 1920s Weimar Republic and Vienna, and in 1950 s Rome.

\section{Tafuri on housing during the Weimar Republic}

For Tafuri and his collaborator Francesco Dal Co, the Siedlungen built around Frankfurt and Berlin in the 1920s were a development from the anarchic-libertarian utopias of Expressionism. They embodied a radical alternative avant-garde that gave primacy to the rationalization of territory and industrialization of building processes. Renouncing the role of high priest in the cathedral of the future, the architect willingly demoted himself to technician controlling building production and territorial development (Tafuri and Dal Co, 1980, p. 153). This rationalist avant-garde retained from its earlier incarnation a concern with the totality of Gesamtkunstwerk, manifested in the attempted accord between architectural language and the conditions of production. The modularity and prefabrication of Weimar housing were conceived as metaphors for the Fordian assembly line. At the level of urban planning, Ernst May in Frankfurt and Martin Wagner in Berlin retained this parallel by developing Siedlungen as satellites disconnected from the nuclear city centres, replicating the decentralization of industry, and relying on infrastructural network for cohesion.

May's visions in Frankfurt and Wagner's in Berlin were utopian in their efforts to root out speculative building, in insisting on housing as a purely social provision rather than commercial commodity. Tafuri believed that the problem with this model of "direct urban control" was its ideological opposition to the principles of modern planning, articulated as a corrective to, rather than the radical rejection of, free-market inequalities. Ludwig Hilberseimer's Grossstadt was more perceptive in its acknowledgment of the extent and depth of capitalist operations (Tafuri 1976, pp. 104-107). If, for May, the residential unit replicated a mechanistic logic, Hilberseimer extended the conception to the entire urban realm as an integrated, compact and stratified "citymachine" (Tafuri 1976, pp. 107, 114). This conception of an alternative to the fragmented islands of the Siedlungen came however at a cost. 
Fig. 1 Hans Scharoun (masterplan) with Fred Forbat, Otto Bartning, Walter Gropius, Paul Rudolph Henning, Hugo Häring. BerlinSiemensstadt, 1929-30. Zeilenbau by Gropius. Photo: Irina Davidovici

Fig. 2 Bruno Taut and Franz Hillinger for GEHAG. Wohnstadt Carl Legien, Berlin, 1928-30.

Photo: Irina Davidovici
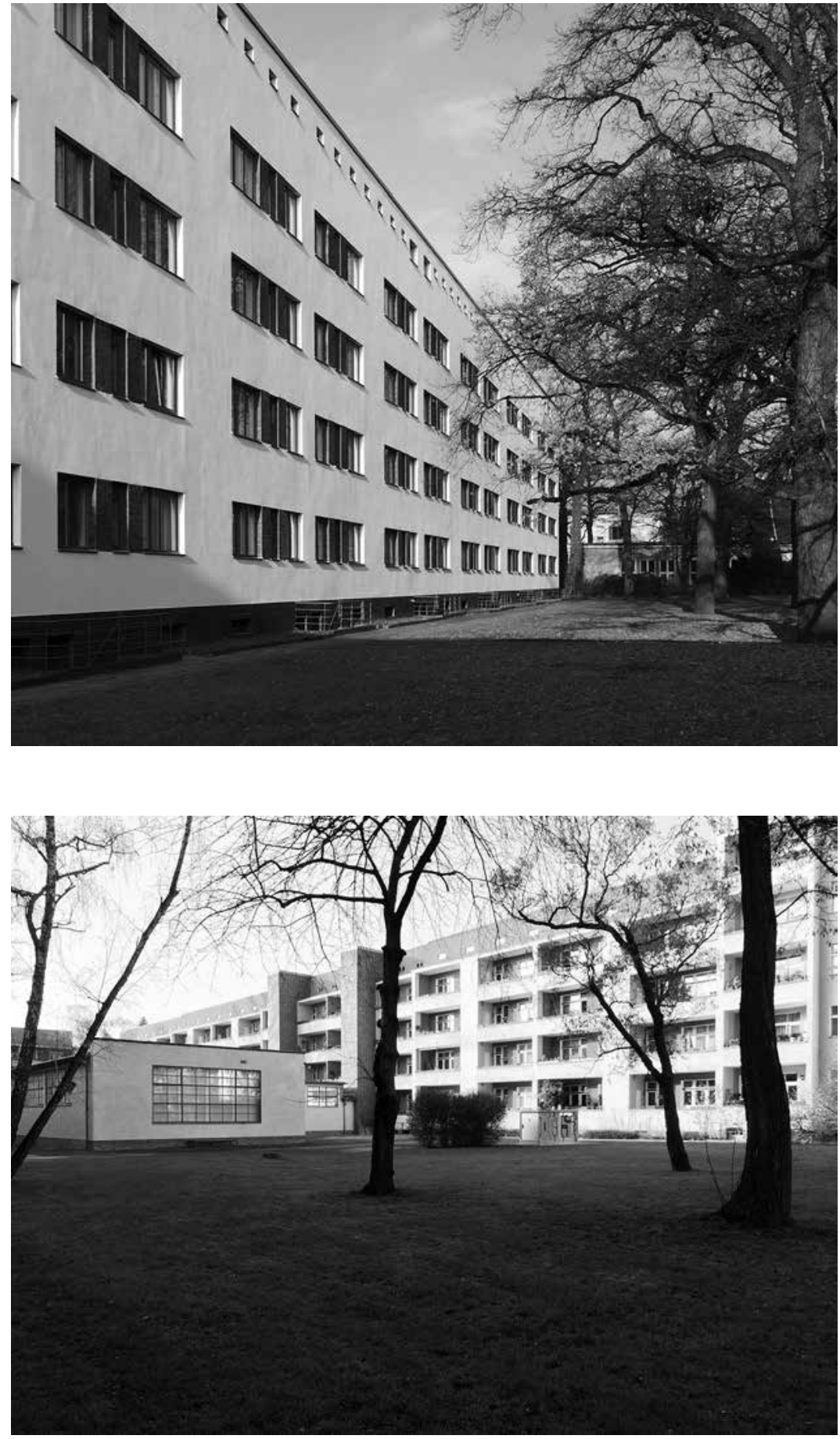
The acceptance of the metropolis as pure system, as the expression of concentration of capital, rendered it "anonymous, compact, stratified": a naked infrastructure for impersonal processes, "a city without qualities" (Tafuri and Dal Co, 1980, p. 162). The ambiguous locations of dwelling and work became interchangeable, caught in the expression of the same inexorable logic.

Tafuri posed the dual strategies of Weimar urban policy as extreme solutions with no median ground. In Hilberseimer's machinecity, the question of housing remained abstract, a matter of skeletal infrastructure as impersonal as the Taylorian production processes to which it owed its existence. Whereas, in their search for communal values, as the embodiment of their planners' social democratic values, the Siedlungen represented an anti-urban ideology, based on the utopian order of autonomous garden cities: "the closed economy of the settlements reflected the fragmentary character of the undertakings that left intact the contradictions of the city" (Tafuri, 1976, p. 115). Even with political support and the elimination of private enterprise, this "closed economy" failed to address the dynamic of the capitalist city or the financial aspects of real estate. The impossibility of controlling economic aspects, such as credit and cost materials, effectively neutralized its results. So, while the production of housing progressed significantly in intellectual and architectural terms, its actual limits were set out by the underlying ideology.

\section{Tafuri on Red Vienna's Gemeindebauten}

The circumstances of post-Habsburg Vienna as a socialist capital, cut off from the rest of the country and unable to expand outwards in politically inimical territory, dictated an intensive housing program focused, by necessity, on urban densification. Working against the dispersion of working classes into garden cities, the authorities supported the construction of superblocks combining residential and communal facilities located in central urban areas, close to transport infrastructures. The radical policy of the Viennese socialist authorities was financed through land and property requisitions and the levy of taxes as a way to redistribute wealth. Almost 64,000 units were built between 1923 and 1934, which accounts for the strong presence of the socialist Höfe in the city. Here, ideology was coupled to an explicit iconological program, meant to bestow upon working-class housing a dignity and scale previously reserved for aristocratic palaces. However, the price tag of this policy was both economic and political, intensifying the national financial crisis, leading to economic stagnation, and estranging entrepreneurs and property owners, who contributed in turn to the rise of right-wing extremism.

Throughout Tafuri's work, Red Vienna's Höfe and Gemeindebauten recur as counterparts to the Siedlungen being built at the time in Germany: eccentric of the avant-garde agenda, and conspicuously absent from Architecture and Utopia ${ }^{3}$.This deliberate omission is more 


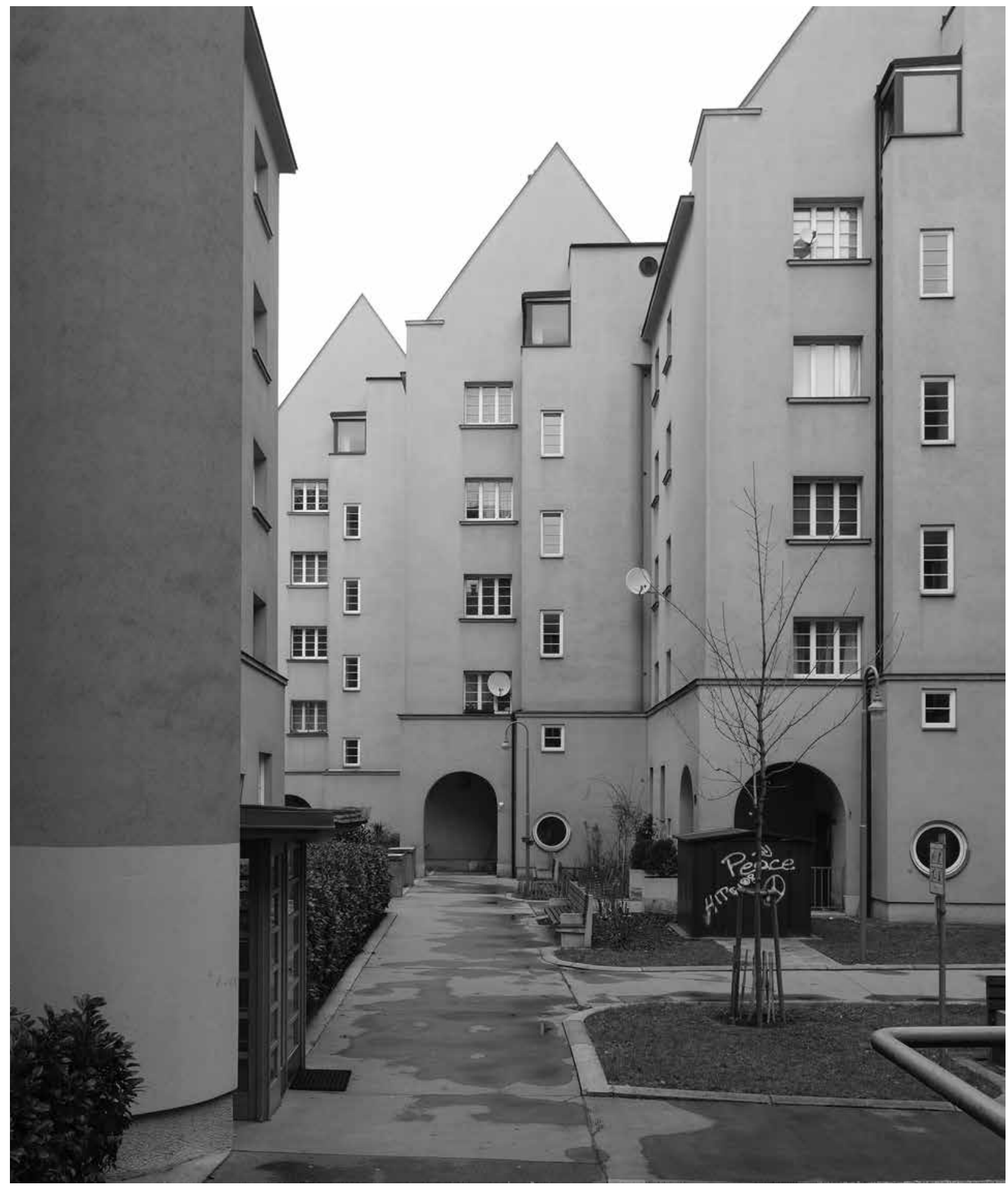

Fig. 3 Heinrich Schmidt and Hermann Aichinger.

Julius-Popp-Hof, Vienna, 1925-27. Internal

courtyard.

Photo: Irina Davidovici 


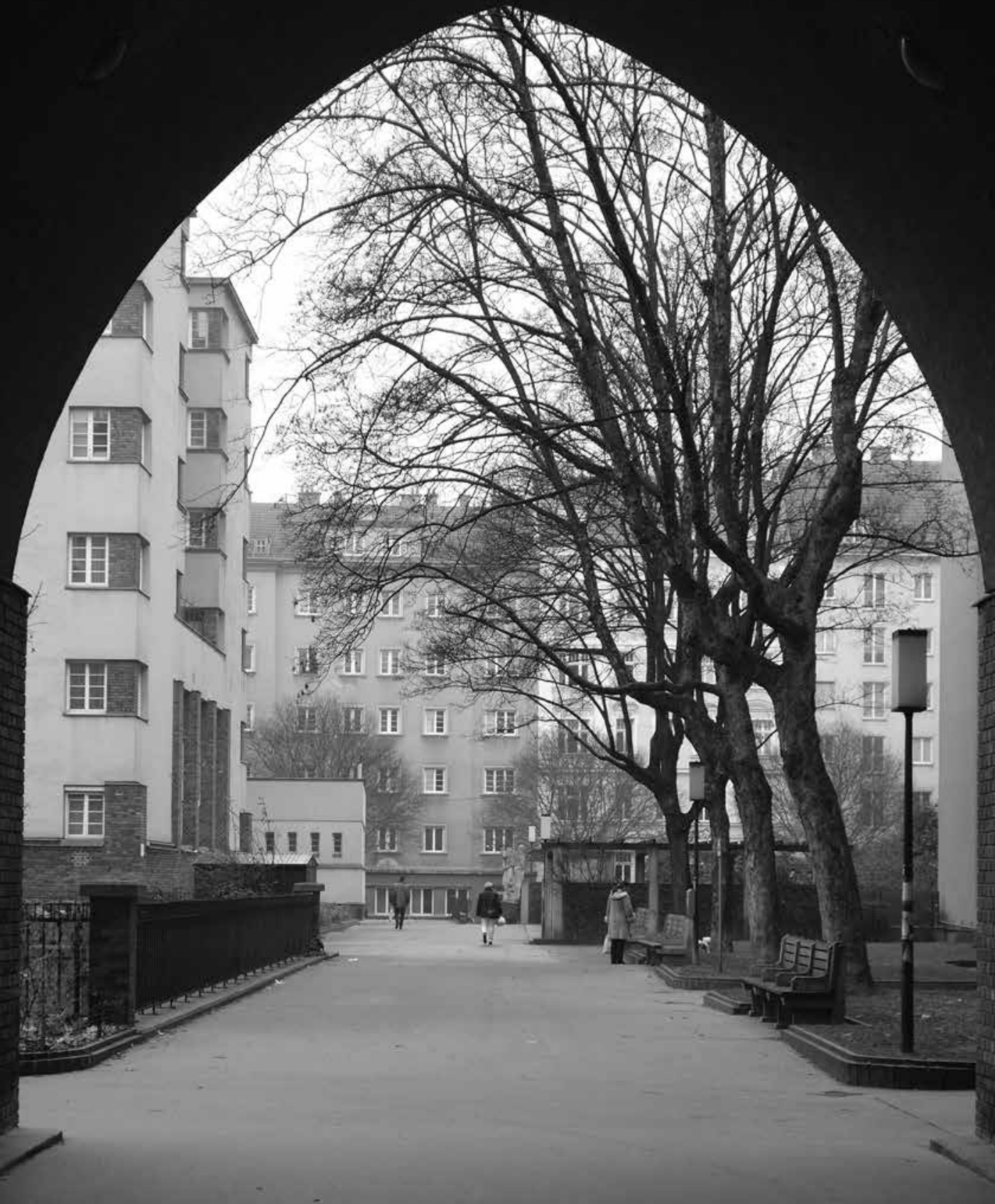

Fig. 4 Heinrich Schmidt and Hermann Aichinger. Rabenhof, Vienna, 1925-28. Arch passageway to internal courtyard.

Photo: Irina Davidovici 
than made up in the substantial Vienna Rossa, hailed by Eve Blau as surpassing all previous historical accounts in its "impact [and] critical authority" (Blau, 1999, p. 11). For Tafuri, the Red Vienna "project of reclaiming" the city for the working classes was from the outset a "dead end", animated by idealistic intentions without considering their long-term feasibility. This naïve idealism was, for him, the outward manifestation of an underlying conflict caused by the misalignment of technology, ideology and form (Tafuri, 1980, p. 7). The scale and outward opulence of the "people's palaces" was largely rhetorical, embodying the illusory attempt to re-configure the capitalist metropolis as an educational and welfare institution (Blau, 1999, p. 12). Tafuri and $\mathrm{Dal}$ Co presented the grandiosity and scale of these projects as a political provocation, "pugnacious islands proclaiming themselves proletarian monuments of very different dimensions and form from the architecture of 19th century Vienna surrounding them", "eager the exalt the autonomous values of a residential democracy that was placed under the aegis of the working class" (Tafuri and Dal Co, 1980, p. 164).

Apart from the urban strategy (mostly inner-city consolidation rather than decentralization), what distinguished the Red Vienna projects from the contemporaneous German housing was a reliance on cultural, rather than technological, symbolism in the formation of their typology. The appeal to the local motif of the connected urban courtyard, at once nostalgic and politically provocative through its emphasis on autonomy, was symptomatic of a recovery of 'place' that prefigured the postwar re-emergence of history as design source. Thus, the Viennese Höfe represented an ambiguous position, at the same time closing within their walls the idealized fragments of a better society, creating an impressive urban presence in scale, and seeking to remain legible to the wider public through 'local' and familiar references. While Tafuri construed this formal consistency as pure isolation, implicitly critical of the speculative piecemeal urban reality surrounding them, Eve Blau saw it differently. To her, the network of pathways that consistently opened up the interior of these blocks connected them to the public realm. Sometimes open to, other times engulfing the street network, the Höfe created a more ambiguous spatial continuity, "like a figure-ground inversion of the traditional city street and block" (Blau, 1999, p. 270).

Tafuri's focus on moments of rupture led him to characterize the housing of Red Vienna as the embodiment of a conflict between ideological content, technological possibilities, and regressive forms. The eschatological monumentality of the Höfe masked a reality of backward industries, political ambivalence and economic crisis. Marxist and utopian, defined by the tension between reform policies and revolutionary aims, Red Vienna remained a political impasse, "a declaration of war without any hope of victory" (Tafuri, 1980, p. 7). 
Tafuri on post-war housing in Rome: The case of INA Casa

From the complementary interwar experiments of Weimar Germany and socialist Vienna, Tafuri turned his attention to a nearer setting, both historically and geographically, in his History of Italian Architecture (1989). Here, the vehicle of the historical survey was used as a means to construct a wider critique of Italian postwar reconstruction, seen as posing a "difficult dialectic between knowledge and action", based not only on contradictions within architecture but with its wider conditioning (Tafuri, 1989, p. 3). After the war, as part of the intellectual production, architectural practice was viewed as inexorably political. It was distinguished by successive ideologies, connected by the ethical imperative of what Tafuri called "the pursuit of a program of truth" (Tafuri, 1989, p. 4). The contents of this truth and the basis for action remained, however, open to interpretation. In a program of cultural cohesion, the dilemma of having to choose between the emulation of appropriate historical models and erasing the recent past opened, Tafuri argued, an intellectual conflict with tradition. The need to overcome the problematic political connotations of interwar idioms, whether rationalist or neoclassical, led to the adoption of a popular language, relatable to the experience of inhabitants. In this intellectual context, the postwar production of INA-Casa was subsumed under the agenda of Neorealism. In its appeal to the common symbols of an untainted past in order to purify the future, Neorealism represented a "contamination between individual and collectivity, between parts and whole" (Tafuri 1989, p. 10).

The Tiburtino district in Rome is a case in point: for Tafuri, its Neorealism was symptomatic of the identity crisis besetting at this time the Italian creative classes. Through immersion into rhetorical nostalgia, the design sought solace in the familiar confines of traditional forms and details. The Tiburtino's distance from the city centre, while the result of INA CASA's ill-conceived, financially motivated urban strategy of urban sprawl, was re-construed as a form of freedom to claim the life of a real village (Tafuri, 1989, p. 16). This rural fiction was formally translated into the sinuous planning of streets and piazzas, predominantly one-family house types, with a profusion of vernacular details only vaguely related to traditional architecture. The necessary reliance, at the time, on low-tech construction was likewise transformed into a celebration of craftsmanship as "antidote for alienation" (Tafuri, 1989, p. 17). Tafuri remained sceptical of this fabricated rural idyll, problematized by the recycling of its artificial cosiness and populist detailing as a "facile formula offering materials for easy use and consumption" (Tafuri, 1989, p. 3).

Ridolfi and Franckl's ensemble of residential towers on the more urban location of Viale Etiopia, on the inside of the Circonvallazione, represented for Tafuri "one of the greatest testimonies of the intellectual anxiety experienced in the 1950s" (Tafuri, 1989, p. 18). In the new quartier, the artisanal enamel panelling and pastel colour 

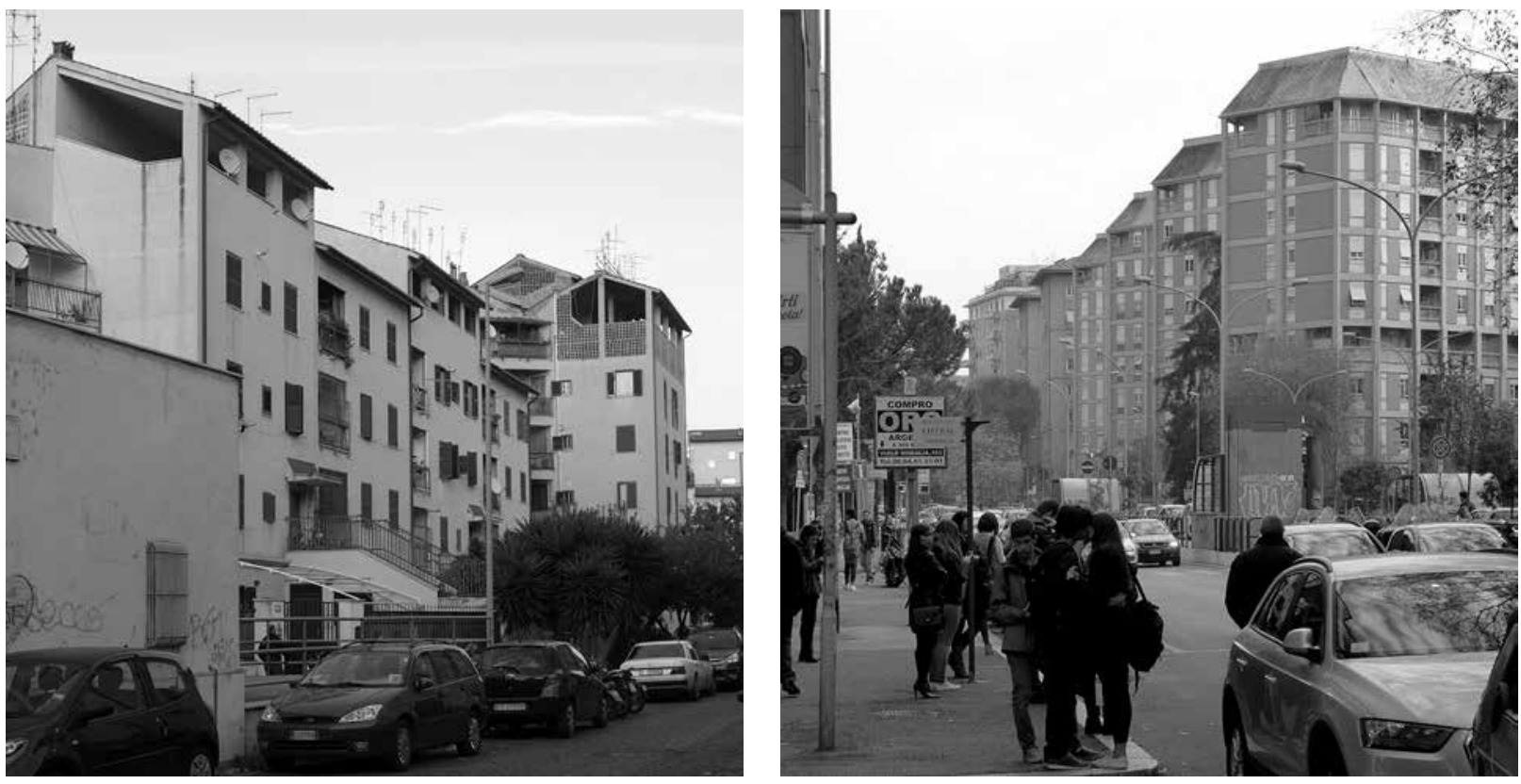

Fig. 5 Ludovico Quaroni and Mario Ridolfi (project leaders), Carlo Aymonino, Carlo Chiarini, Mario Fiorentino, Federico Gorio, Maurizio Lanza, Sergio Lenci, Piero Maria Lugli, Carlo Melograni, Giancarlo Menichetti, Giulio Rinaldi, Michele Valori. INA-Casa District on Via Tiburtina, Rome, 1949-54.

Photo: Irina Davidovici

Fig. 6 Mario Ridolfi and Wolfgang Frankl. INAAssicurazioni residential towers, Viale Etiopia, Rome, 1950-54.

Photo: Irina Davidovici scheme amounted to a kind of prettiness, only to be undercut by the tectonic heaviness of the dominant structure. Through the contrast between the austere concrete frames and soft decorative scheme, the project commented on a disjointed urban reality, expressing its architects' "painful participation in a human condition that cannot be assuaged with architectural "certainities'" (Tafuri, 1989, p. 18). This drama was expressed in the intuitive, picturesque placement of the towers, denying the positivist agenda associated with modernist highrise, and acknowledging instead an older, more decorous urbanity through the softening effect of their chamfered corners. For Tafuri, the project's adaptation to the social and climatic conditions of its locale moved beyond a regressive utopian narrative to announce instead "the architect's passage from neorealism to realism" (Tafuri, 1989, p. 19).

As consistently in the case of housing, Tafuri subsumed the assessment of purely architectural decisions under the wider problematic of territorial planning. From an administrative point of view, the historian was quick to question the soundness of INA Casa's urban expansion policies, pointing out that their building developments and infrastructural networks, paid for with public money, served to stimulate an objectionable kind of building speculation, which soon engulfed INA Casa districts within inferior, piecemeal and chaotic spread. Moreover, the neorealist rejection of clearly defined, abstract representational means gave rise to a sense of visual confusion, making it difficult to distinguish between populist and popular, between the feigned spontaneity of neorealism and the problematic spontaneity of 
speculative development. Whereby Tafuri had been able to read the earlier examples of Weimar Siedlungen and Viennese Höfe as "oases of order", here the very possibility of order, however fragmentary or compromised, was renounced:

The encirclement of the "districts" by the speculating city - a predictable and calculated phenomenon - soon revealed that architectural design had not managed to produce even islands of realized utopia. Realism showed itself for what it was, the product of a useless compromise (Tafuri, 1989, p. 33).

\section{White Writing}

While his housing analyses focused on specific historical contexts, Tafuri's conclusions repeatedly arrived at a common underlying narrative of conflict, fragmentation and crisis. The inability of parallel and successive ideologies to acknowledge the operations of capital and fully engage with their consequences in the industrial city confirmed, time and again, the limitations of architectural operations when conceived in aesthetic isolation. The following passage from Architecture and Utopia - moving from the historical towards the critical end of the Tafurian spectrum - summarized this dilemma:

Beside the oases of order that were the Siedlungen - true constructed utopias, on the margins of an urban reality little affected by them - the old cities continued to accumulate their contradictions. And for the most part, these contradictions would soon appear more vital than the tools established by the architectural milieu to control them (Tafuri, 1976, p. 109).

It is precisely this spontaneous vitality that became the elusive goal of architecture in the 1970s, not least in dialogue with Tafuri's own discourse. Massimo Scolari's Tendenza manifesto, in 1973, for a new architecture "without compromises, but also without dreams", acknowledged a sense of "renouncement" grounded in "historical awareness" (Scolari 1973, p. 131). Aldo Rossi's question/ answer session, at the beginning of his Scientific Autobiography, conveyed a similar spirit: "To what, then, could I have aspired in my craft? Certainly to small things, given that the possibility of great ones was historically precluded" (Rossi, 1981, frontispiece). Tafuri incorporated the historical awareness of his contemporaries in the framework of an irretrievably fragmented culture, setting in motion an exasperating dialogue of reflections mirroring each other. Rossi's 1975 watercolor L'Architecture assassinée, poignantly dedicated to Manfredo Tafuri, was subsequently placed onto the cover of Architecture and Utopia, acknowledging Rossi's project as effectively architectural criticism that is, a critical attitude expressed by and through architecture itself (Stoppani, 2010, p. 218). 
The Tafurian dilemma of a modern architecture whose aesthetic and operative possibilities are constantly under threat was seen by Fredric Jameson as formulating a "dialectical history of architecture" (Jameson, 1985). For Jameson, Architecture and Utopia belonged to a critical genre of dialectical histories, as articulated in Theodor Adorno's Philosophy of Modern Music (1947) and Roland Barthes's Writing Degree Zero (1953) (Jameson, 1985, p. 57; Adorno, 2003; Barthes, 1984). All three shared the recognition of "necessary failure, of closure, of ultimate unresolvable contradictions" as the very basis of artistic production (Jameson, 1985, p. 58). The artist starts anew with what Jameson called "white or bleached writing", a neutral production that escapes "the nightmare of history" by placing itself outside established stylistic tropes, traditional institutions and particular audiences (Jameson, 1985, p. 61).

To be sure, white writing is a utopian condition that must perpetually re-invent itself. Barthes showed that the discovery of such "a sort of basic speech" becomes inevitably re-engulfed into history: through consumption, "society demotes writing to mere manner, and returns [the writer] as prisoner to his own formal myths" (Barthes, 1984, p. 65). In the end, "writing is a blind alley, because society itself is a blind alley" (Barthes, 1984, p. 72). The dilemma is yet more visible in architecture, given its dependency on social, economic and political factors outside of the discipline. Thus Jameson:

If the outer limit of the individual building is the material city itself, with its opacity, complexity, and resistance, then the outer limit of some expanded conception of the architectural vocation as including urbanism and city planning is the economic itself, or capitalism in the most overt and naked expression of its implacable power (Jameson, 1985, p. 61).

\section{Moving between scales}

Where does this leave, then, the architectural historian, specifically the historian focused on the intricate web of dependencies and ideological narratives underpinning the history of hous-ing? In Theories and History, Tafuri presented the architectural crisis of the modernist avantgarde, in which the formal qualities of projects are at odds with their involvement in a political, social and historical context, as replicated at a methodological level in a crisis of architectural historiography. The limited effectiveness of ideologies and architectural semantics was paralleled by the limited effectiveness of critical tools, which must be continually reinvented. Tafuri's dialectical historiography shifted the focus of analysis from buildings to the historical phenomena they symptomized; from criticism, to the study of history. In an interview with Richard Ingersoll, he advocated an understanding of architectural form in the context of its determining societal and economic processes: 
As to how to select buildings that are worthy of history, it is the problem and not the object that concerns the historian. The works selected are irrelevant on their own and only have meaning in the way they relate to the problem.... As to the problems of architecture, it is more interesting to note cycles - series of things - rather than individual works of architects. The historic cycle tells us more than stylistic taxonomies (Tafuri, 1986, pp. 8-11).

Thus, the strategy required of housing historians goes beyond the, by now, self-evident imperative of subsuming the analysis of the architectural object under the analysis of its historical, political, social and cultural conditions of production. It requires them to operate with the recognition that, rather than reflecting society, housing inscribes itself in self-perpetuating cycles of consumption and investment, which explains its inability to meet the more dynamic needs of changing demographics. Housing is by definition tied into standardization, rendered repetitive and limited in configurations, becoming a major contributor to the monotony of cities (not by any means the worst that an urbanization operation can do).

This is however not enough. In a wider understanding of architecture, housing is tied into processes that determine urbanization, and thus impacts on the character of emerging cities. David Harvey identified another level of inevitability, besides the 'micro' problem of white writing or degree zero architecture, at the macro scale, in what he called "the capital surplus disposal problem" (Harvey, 2007). Harvey argued that the economic need to perpetually reinvest profit leads, with implacable logic, to urbanization as an outlet for capital. The capital surplus problem is cyclical for it is unresolvable, providing ever "temporary solutions" that nevertheless, in the course of implementation, impact irreversibly and in the long term upon the quality of urban life (Harvey, 2007, p. 17). As a result of such operations, under global neo-liberalism "cities have increasingly become cities of 'fortified fragments', in which the barriers between social classes are ever more strongly articulated (Harvey, 2007, p. 23; National Research Council, 2003, p. 379).

The "fortified fragments" that Harvey cites are altogether different from Tafuri's reading of reformed housing as "oases of order" in interwar Frankfurt, Berlin or Vienna. They are more a sequel to the "uselessly compromised" developments he identified on the outskirts of postwar Rome (to which one might easily add London, Paris, Amsterdam and almost any other European city). Experimental housing reforms, both before and after the Second World War, proposed models of democratic and equalitarian societies, whether nostalgic or utopian, through the design of orderly and controlled pockets of utopia. In Harvey's current account, the urban fragmentation is yet more profound, as demonstrated by the aggravation of social inequality and potential conflict in the neo- 
liberalist metropolis. More than ever, therefore, the historian of housing must learn from Tafuri the difficult but indispensable skill of lucid analysis of housing in its complex contexts. Jean-Louis Cohen noted how Tafuri "ceased to exalt the heroism of pioneers and the radicalism of avant-garde manifestos, inscribing their production in a vaster history: not that of architectural movements, but of the consolidation of capitalist modes of production that metropolitan culture gives expression to" (Cohen 2015, p. 161). A necessary stage in the history of housing might thus be to explain the rapport of architects to existing political and financial hegemonies: their role as active collaborators and shapers of policy, or, as is increasingly the case, as unquestioning service providers, cladding over ever more normalized and generic configurations. The historian of housing should offer a reflecting surface for its practitioner by articulating and clarifying these rapports.

Marco de Michelis comes closer to identifying, within Tafuri's historical project, his methodological approach. "For Tafuri", he writes, "the peculiar aim of history is not a mere 'hermeneutic' production of interpretation, but rather much more a production of meanings through the 'constant struggle between analysis and its objects'... an analytical construction that is never definitive and always provisional" (de Michelis, 2017, p. 16). Analysis must constantly shift between, on the one hand, the articulation of built forms within the urban fabric, and on the other the societal and economic processes that shape both building and city. Thus, it may identify the misalignments produced by the juxtaposition of obdurate capitalist logic against more fluid processes of technological and societal transformation. Housing is not only about industrial production, but also, fundamentally, social reproduction. The historian's perspective thus engages with cycles of cultural production and economic enterprise, intertwined in endless discourse. Understood as a discursive practice, the history of housing as a history of ideas reveals fundamental mechanisms in the production of urban space.

$1 \rightarrow$ See for example Panerai, Castex, Depaule, Samuels 2004; Sonne, 2017.

$2 \rightarrow$ For the activities of the Istituto at Tafuri's time see Cohen, 2015,

pp. 137-166.

$3 \rightarrow$ The brief but intense attention accorded to Red Vienna in Tafuri and Dal Co's

Architettura contemporanea (1977, English translation 1980) was supplemented by

closer-grain analysis in the anthology Vienna Rossa. La politica rezidentiale

nella Vienna socialista (1980). Both were outcomes of a longer-term project,

starting in 1969 with investigations into the Viennese residential type as

"anomalous" in the context of European avant-gardes (Tafuri, 1980, p. 5).

Tafuri's earliest article on this topic was "Austromarxismo e città 'Das Rote

Wien'" (Tafuri, 1971), and it was lastly visited was published in "Realismus

und Architektur: zur Konstruktion volksbezogener Sprachen" (Tafuri, 1987). 


\section{References}

This article is a reworked and expanded version of the paper presented at the conference Once upon a Time: Manfredo Tafuri and the Crisis of Architectural History, ETH Zurich, 6 March 2015. This research was conducted with the support of the Marie-Heim Vögtlin Program of the Swiss National Fund for Research, 2014-2016.

Adorno, T. W. (2003). Philosophy of Modern Music. New York: Continuum.

Barthes, R. (1984). Writing Degree Zero. In Writing Degree Zero and Elements of Semiology (pp. 1-43). London: Jonathan Cape.

Blau, E. (1999). The Architecture of Red Vienna, 1919-1934. Cambridge, MA: MIT Press.

Cohen, J.-L. (2015). La coupure entre architectes et intellectuels, ou les enseignements de l'Italophilie, Bruxelles: Mardaga.

Dal Co, F. and Tafuri, M. (1980). Modern Architecture, vol. I. London: Faber \& Faber and Milan: Electa

de Michelis, M. (2017). Manfredo Tafuri and the Death of Architecture. In Stoppani, T., Ponzo, G., and Themistokleous, G. (Eds.), This Thing Called Theory (pp. 9-20). London: Routledge.
Harvey, D. (2007). The Freedom of the City. In Swenarton, M., Troiani, I., and Webster, H. (Eds.), The Politics of Making (pp. 15-24). London: Routledge.

Hays, K. M. (1998). Architecture Theory Since 1968. Cambridge, Massachusetts: MIT Press.

Jameson, F. (1985). Architecture and the Critique of Ideology. In: Ockman, J. (Ed.), Architecture Criticism Ideology (pp. 51-87). Princeton, New Jersey: Princeton Architectural Press.

Panerai, P., Castex, J., Depaule, J.-C., and Samuels, I. (2004). Urban Forms: The Death and Life of the Urban Block. Oxford: Architectural Press.

Rossi, A. (1981). A Scientific Autobiography. Cambridge, Massachusetts: MIT Press.

Scolari, M. (1973). The New Architecture and the Avant-Garde. In K. M. Hays (Ed.), Architecture Theory since 1968 (pp. 126-145). Cambridge, Massachusetts: MIT Press.

Sonne, W. (2017). Urbanity and Density in $20^{\text {th }}$ Century Urban Design. Berlin: DOM.

Stoppani, T. (2010). L'histoire assassinée: Manfredo Tafuri and the present. In Bandyopadhyay, S., Lomholt, J., Temple, N. and Tobe, R. (Eds.), The Humanities in Architectural Design: A Contemporary and Historical Perspective (pp. 214-225). London: Routledge.
National Research Council (2003). Panel on Urban Population Dynamics. Cities Transformed: Demographic Change and Its Implications in the Developing World. London: Earthscan.

Tafuri, M. (1969). Per una critica dell'ideologia architettonica. In Contropiano 1, 31-79.

Tafuri, M. (1971) Austromarxismo e città 'Das Rote Wien'. In Contropiano 2, 259-311.

Tafuri, M. (1976). Architecture and Utopia: Design and Capitalist Development. Cambridge, Massachusetts: MIT Press.

Tafuri, M. (1980). Vienna Rossa: La politica residenziale nella Vienna Socialista. Milano: Electa.

-

Tafuri, M. (1986). There is no criticism, only history. Interview by Richard Ingersoll. In Design Book Review 9, 8-11.

Tafuri, M. (1987). Realismus und Architektur: zur Konstruktion volksbezogener Sprachen. In V. Magnago Lampugnani (Ed.), Das Abenteuer der Ideen. Internationale Bauausstellung Berlin 1987 (pp. 131-48). Berlin.

Tafuri, M. (1989). History of Italian Architecture, 1944-1985. Cambridge, Massachusetts: MIT Press. 